\title{
Hazardous Events on the Black Sea Rivers, Their dynamics and Regulation
}

\author{
Tsisana Basilashvili \\ Institute of Hydrometeorology, Georgian Technical University, Tbilisi 0112, Georgia
}

Received: January 15, 2015 / Accepted: January 25, 2015 / Published: February 25, 2015.

\begin{abstract}
The historical, informational and literary sources regarding flooding have been studied. Based on the statistical processing of multiyear stationary observation data the river maximal discharge parameters are specified. According tendency of their dynamics the flooding strengthening has been revealed on rivers nourished by glaciers, on the contrary in other rivers they reduced, in some regions evaporation has been increased and desertification has been detected. For mitigation negative impacts of those processes the recommendations of prevention measures are drafted.
\end{abstract}

Key words: River water discharge, flooding, climate change, forecasting method.

\section{Introduction}

Current climate change caused air temperature rising, disruption of climatic cycles. In connection with global climate change on the Earth the number of catastrophic floods has been enormously increased and caused great damages. This problem is especially urgent for Georgia where high waters and continuous floods are preconditioned by the landscape-climatic state. On each spring season mountainous rivers and dry gaps run in strong flows toward to the lowlands.

Except of spring floods on Georgian rivers take place high waters at any season of year that in rainy periods take catastrophic character. Also because of the growth of anthropogenic impact (elimination of lakes and growth) the high water increases, that caused irreversible destruction to the separate regions, population, industry, nature and ecological state. Especially during last 20 years in Georgia there were repeated large-scaled catastrophes in several times, that damaged economy significantly [1].

As it is known river discharge for giver relief is variable. But still there doesn't exist method that

Corresponding author: Tsisana Basilashvili, Ph.D., research fields: hydrometeorology, ecology and forecasting. E-mail: jarjinio@mail.ru. perfectly describes river discharge variation, as this variation in conditioned not only by local factors but also helio-synoptical processes which consideration is difficult. Besides that, present eustasy-uniform worldwide change in sea level caused by water thermal expansion, imbalance of fresh waters between the land and the ocean in favour of the ocean, seriously threatens Black sea coastline, where the sea level has raised by $20 \mathrm{~cm}$ and this is a continuous process with unfavorable forecast.

\section{Study Area}

In Georgia river water content has been accounted from 30th years of XX Century. For characterization of observation series deviation methods of mathematical statistics are used in hydrology. The river water maximal discharge observation line elements are random quantities and varying from arithmetical middling values. The variation line main characters of Georgian Black Sea river maximal discharges: arithmetical middling (norm), members of its variation (variation $\mathrm{Cv}$ and asymmetry $\mathrm{Cs}$ ), biggest values and others are given in Table 1 . Mentioned data have great practical significance in water economy calculations especially now when observation post has been sharply reduced and only river levels are 
measured.

The calculations of river discharge expected change for economical organizations is important using well-known probability curves that corresponds the issue: what is the assurance of construction or some measurement at definite values of river discharge. For construction of such curves and calculation of river maximal discharge probable values the graph-analytical method [2] is used. The obtained 1\%, $2 \%, 5 \%$ and $10 \%$ probability (corresponding 100,80 , 20 and 10 year frequency) maximal discharges are given in table. The frequency indicates on that year number when maximal discharge happens only once in average. It is remarkable that according probability values calculated by past year data are less than present values. For example 1\% probability discharges exceeds calculated discharges up to 1962 on $15 \%-20 \%$, that is caused by climate global change.

From practical point of view for all type of hydrotechnical construction the identification of water maximal discharge of different probability types but also its maximal threshold values. For this the flooding activity members are used, calculated by dividing river maximal discharge $\left(\mathrm{Q}_{\max } \mathrm{m}^{3} / \mathrm{sec}\right)$ to its mean annual discharge $\left(\mathrm{Q}_{0} \mathrm{~m}^{3} / \mathrm{sec}\right)$ : $\mathrm{Q}_{\max } / \mathrm{Q}_{0}$ values for Caucasus Region has been calculated firstly using 1974 year data in Ref. [3] work. Those members calculated by authors for Black Seaside River using new data are given in table.

By relevant analysis in Ref. [4] work is identified that flooding activity members reduce according increasing of river watershed basin square, their mean height, river water mean annual discharge and atmospheric precipitation. Or these members are more for little rivers than for big rivers, under wet environment conditions they are less than under dry conditions, in mountains their values decreased by height growth.

\section{Results and Discussion}

For assessment of further development of flooding the hydrometeorological processes variation dynamics study considering anthropogenic factors and climate global change became more urgent. For this the multiyear variation of river water maximal discharge causes great interest. In Fig. 1, the multiyear variation

Table 1 River water maximal discharge $\left(\mathrm{Q}, \mathrm{m}^{3} / \mathrm{sec}\right)$ characteristics.

\begin{tabular}{|c|c|c|c|c|c|c|c|c|c|c|c|c|}
\hline \multirow{4}{*}{ River-post } & \multirow{4}{*}{$\begin{array}{r}\text { Area } \\
\mathrm{km}^{2}\end{array}$} & \multirow{4}{*}{$\begin{array}{c}\text { Height } \\
\text { m. }\end{array}$} & \multirow{4}{*}{$\begin{array}{l}\text { Annual } \\
\text { mean } \\
\text { disch. } \\
\mathrm{Q}_{0}\end{array}$} & \multirow{4}{*}{$\begin{array}{l}\text { Mean } \\
\text { max. } \\
\text { disch. } \\
\mathrm{Q}_{\max }\end{array}$} & \multirow{4}{*}{$\mathrm{Cv}$} & \multirow{4}{*}{ Cs } & \multirow{4}{*}{$\mathrm{Q}_{\max }$} & \multirow{4}{*}{$\frac{\mathrm{Q}_{\max }}{\mathrm{Q}_{0}}$} & \multicolumn{4}{|c|}{ Provision \% } \\
\hline & & & & & & & & & 1 & 2 & 5 & 10 \\
\hline & & & & & & & & & \multicolumn{4}{|c|}{ Frequency, year } \\
\hline & & & & & & & & & 100 & 80 & 20 & 10 \\
\hline Bzipi-Jirkhva & 1,410 & 1,690 & 98.2 & 502 & 0.37 & 4.4 & 1,890 & 19.2 & 1,315 & 1,100 & 844 & 669 \\
\hline Kodori-Lata & 1,480 & 1,920 & 92.5 & 467 & 0.4 & 4.9 & 1,240 & 13.4 & 1,310 & 1,084 & 804 & 617 \\
\hline Enguri-Khaishi & 2,780 & 2,320 & 118 & 507 & 0.54 & 4.5 & 1,190 & 10.1 & 1,530 & 1,299 & 984 & 783 \\
\hline Khobi-Legakhare & 310 & 1,640 & 21.6 & 202 & 0.64 & 4.2 & 536 & 24.8 & 773 & 623 & 446 & 323 \\
\hline Rioni-Oni & 1,060 & 2,260 & 44.8 & 178 & 0.34 & 0.6 & 382 & 8.93 & 319 & 300 & 277 & 255 \\
\hline Rioni-Alpana & 2,830 & 1,810 & 103 & 630 & 0.43 & 4.2 & 1,470 & 14.3 & 1,808 & 1,506 & 1,134 & 880 \\
\hline Rioni-Sakochakidze & 13,300 & 2,620 & 399 & 1805 & 0.4 & 1.5 & 5,500 & 13.8 & 4,236 & 3,805 & 3,236 & 2,776 \\
\hline Kvirila-Zestaphoni & 2,490 & 960 & 60.7 & 513 & 0.34 & 0.5 & 1,100 & 18.1 & 958 & 896 & 807 & 732 \\
\hline Dzirula-Tseva & 1,190 & 880 & 26 & 300 & 0.3 & 2.7 & 595 & 22.9 & 655 & 581 & 481 & 408 \\
\hline Khanistskali-Baghdati & 695 & 1,230 & 15.9 & 118 & 0.48 & 1.2 & 209 & 13.1 & 294 & 264 & 226 & 193 \\
\hline Tskenistskali-Luji & 506 & 2,240 & 24.4 & 115 & 1.03 & 5.2 & 188 & 7.70 & 657 & 508 & 320 & 201 \\
\hline Tskenistskali-Khidi & 1,950 & 1,800 & 42.1 & 361 & 0.6 & 2.2 & 721 & 17.0 & 1,156 & 998 & 797 & 650 \\
\hline Supsa-Khidmaghala & 1,100 & 970 & 50.8 & 484 & 0.39 & 3.2 & 692 & 13.6 & 1,219 & 1,043 & 839 & 702 \\
\hline Chorokhi-Erge & 22,000 & - & 278 & 1495 & 0.56 & 4 & 3,840 & 13.8 & 4,803 & 3965 & 3,000 & 2,392 \\
\hline Adjaristskali-Keda & 1,360 & 1,470 & 46.1 & 342 & 0.49 & 1.6 & 770 & 16.7 & 905 & 805 & 671 & 564 \\
\hline
\end{tabular}




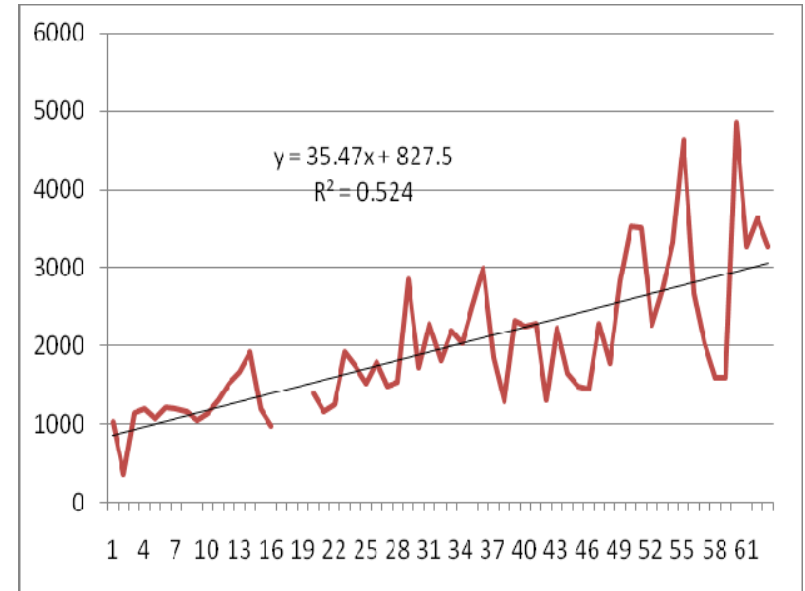

(a)

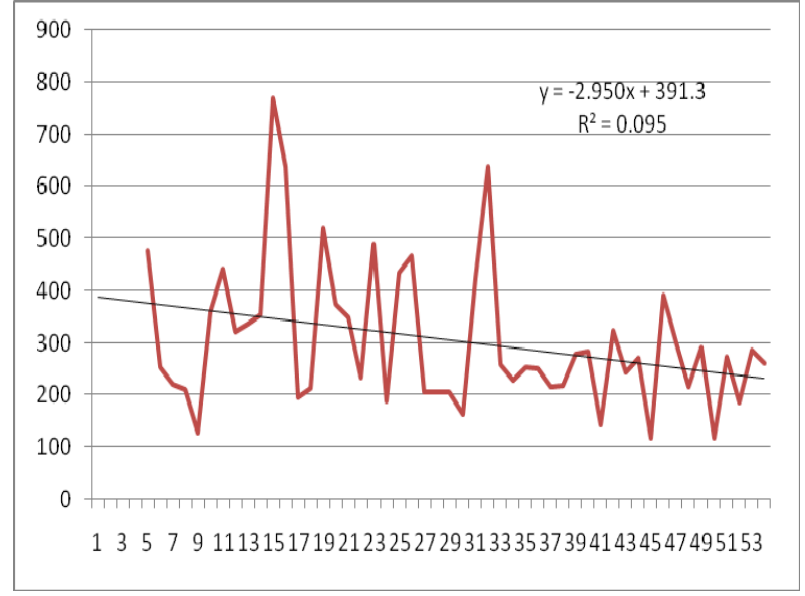

(b)

Fig. 1 The multiyear variation dynamics of river water maximal discharges in River Rioni (a) and Adjaristskali (b).

dynamics of river water maximal discharge is shown on river Rioni (a) on its lower part vil. Saqochakidze which sources are located in Caucasus and according Ref. [4] are 124 glaciers total square $63 \mathrm{~km}^{2}$. On figure is also presented river Adjaaristskali (b) maximal discharge dynamics at vil. Keda in its basin glaciers are absent. River Rioni chart shows maximal discharge growth trend, and on River Adjaaristskali vice versa- maximal discharges reduce.

Averaged values of above said variations-trends are qualitatively assessed with linear regression. The analytical expressions with corresponding dispersion criteria are given at the chart. The river water maximal discharge mutually exclusive trends are caused by the fact that because of global climate warming the glaciers located in river Rioni basin and eternal snow cover have been intensively melted resulted in river discharge growth. Such process is excluded in river Adjaristskali basin where temperature rising causes evaporation growth from basin surface and river water discharges correspondingly reduced.

As the global warming still presents the air temperature growth is expected. These will undoubtedly caused intensification of eternal snow cover and glacier melting and river flooding increasing and in places where glaciers absent the evaporation increases and flooding reduce. Thus in river Rioni the flooding and river water maximal discharge increasing is expected till on its outlet in Caucasus there exist glaciers and in river Adjaristskali flooding and their maximums reduces. According investigations conducted by Prof. Tsomaia "The Caucasus Ridge will became glacier free in 2150-2160 years” [1]. This process in region would cause water resources sharp reduction, spring drying, crop yield and water supply reduction and other negative events that would have harmful effect on environment, society and country development.

\section{Recommendations}

For present time against the background of current climate change the dangerous hydrometeorological events are intensificated. The flooding frequency and damages increase and at the same time in some regions the desertification and water scarcity increase. For the mitigation of negative impacts of those processes the definite adaptation measures have to be conducted, included woodland restoration and enlargement, which is needed for moisture also for moisture deficit eradication and is flooding regulation measure, as wood canopy conserves for long time winter snow cover. Besides forest protects soil and reduces its erosion and desertification.

For river water regulation the most effective are reservoirs, because they can retain high water flows and mitigate catastrophic processes, and during low 
waters they are the basic sources of water resources, which may simultaneously used for various purposes: water supply, irrigation, power generation, fishing recreation-touristic zone and etc.. Thus for mountainous rivers the construction of small reservoirs would be useful. The construction in mountain regions is possible by the deepening of river basins or may be used intermountain depressions. Also natural lakes may be used as reservoirs; the most of them are nonfunctional.

The correct planning of water resources is essential for reservoir to use according to its intended purpose. For this the preliminary definition of the resources is needed. The forecasting of water discharge of Reservoir Rivers for different periods has been performed for this reason. Besides for efficient use of reservoirs as in west as in east Georgia the identification of river flooding and their maximal discharge is necessary, because they threaten not only reservoirs but also environment.

The formation of Georgian river discharge has been realized in different hydrometeorological and physical-geographical conditions. The water regime of each one is characterized by individuality and thus they aren't identical. For this reasons for each river the different forecasting methodic is needed. The flooding discharge is especially important when in rivers passed $60 \%-70 \%$ of all water annual discharges. According flooding discharge prognosis the planning of reservoir rational application has been drown up. For this purpose the authors elaborated long-range forecasts of western Georgia river (Jvari and Vartsikhe) flooding discharges [5] and their maximal runoffs [6].

The forecasting methods are based on the multifactor statistical model, considering precipitation, snow water content and air temperature data. By using their timely and correct information in March it is possible to calculate 3-5 month beforehand forecasts.

Because in Georgia damages caused by flooding and storm water still increase so for safety reasons the conducted of following measures are necessary: regularly clean and deepen river basins, extracted stones may be used in bank seat constructions. The river ravine lope must be terraced and mountain basement water channels have to be passed.

The most easily safety measure from water element is the flooding margin identification and declaration of this zone as dangerous, where all kind of industrial or living activity would be prohibited.

If according March prognosis the expected maximal discharges exceed its mean annual values (norm) and approach to their biggest values then the inhabitants must be informed and their and tangible property have to be evacuated and also environment ecological safety must be provided. For this reason the reservoir gradually timely emptying is essential to obtain further water big flow.

\section{Acknowledgements}

This study was supported by the Grant of the Georgian Shota Rustaveli National Science Foundation No. GNSF/ST08/5-444. Any idea in this research is possessed by opinion of the Foundation itself.

\section{References}

[1] Basilashvili, Ts., Salukvadze, M., Tsomaia, V., and Kherkheulidze, G. 2012. "Catastrophic of Flooding, Mudflow and Avalanches in Georgia and their Safety." Tbilisi: Publishing House "Technical University”, p. 244.

[2] Alekseev, G. 1971. Objective Methods of Adjustment and Normalization of Correlation. Leningrad, p. 264.

[3] Svanidze, G., and Khmaladze, G. 1983. Freshets and Floods, Hazardous Hydrometeorological Phenomena in the Caucasus, Leningrad, pp. 191-210.

[4] Water Resources of Transcaucasia. Leningrad, 1988. p. 264.

[5] Basilashvili, Ts. 2013. Forecasting Mountain River Flows When Having Inadequate Information. Tbilisi, p. 148.

[6] Basilashvili, Ts. 2013. Multifactorial Statistical Methodology for Forecasting Floods-High Water Flows. Tbilisi: Publishing House “Technical University”, p. 180. 